\title{
The Value of Export Incentives
}

\section{Imtiaz Ahmad}

\begin{abstract}
This study develops a methodology for the comparative analysis of industry-specific export incentives. The impact of different export incentives extended to the textiles sector in India, Pakistan, and Bangladesh is analyzed using industry-level data for the years 2001-11. Our findings show that Bangladesh operates a highly export-oriented regime - of the three countries, the value of its export incentives is highest. The study suggests that, in order to maintain its competitiveness in textile exports, Pakistan needs to enhance its export incentives, particularly for value-added textiles.
\end{abstract}

Keywords: Exports, export incentives, fiscal incentives, exchange rate, textiles sector, Pakistan.

JEL classification: F00, F13, L50.

\section{Introduction}

Developing countries have a long history of providing export incentives to reduce the overall tax burden on export incomes, thereby enabling exporters to lower prices without reducing their net profits. Over the years, such incentives have taken several forms, comprising both tax and nontax incentives. These include tax exemptions, export finance schemes, and other measures to facilitate exporters and exporting. Apart from the rationale for enhancing market incentives to attract investment in the exports sector, there are also political motives for export incentives because of which their impact - in terms of economic distortions - is often ignored.

In recent years, export promotion has been the hallmark of most South Asian economies' trade policies. While trade liberalization episodes have generally reduced the anti-export bias, these economies also rely on a variety of direct export measures to facilitate export growth. The overriding principles behind restrictive trade regimes were the protection of domestic industry from foreign competition and the conservation of foreign exchange to support the balance of payments. However, as the

\footnotetext{
* Department of Economics, National University of Sciences and Technology, Pakistan.
} 
South Asian countries transition from development strategies based primarily on import substitution to ones based on export promotion, a number of incentives are being offered to boost exports.

The rationale for using export incentives along with the exchange rate includes, first, the depreciation of the exchange rate, which generally increases the profitability of exports, but runs the risk of leading to more domestic inflation as the prices of essential imports rise simultaneously. Second, the incentive effect is limited in the case of export items that have a high import content. Third, export incentives can be more effective in targeting particular exports, especially emerging and value-added exports.

Export incentives persist as the main ingredient of trade policy. At the same time, they are not subject to strict evaluation primarily because their cost is less visible than that of other export promotion policies that involve explicit budget outlays. This argument is rarely articulated, but it does undoubtedly contribute to the political attractiveness of tax incentives compared to alternatives with a direct budgetary impact, such as subsidies or infrastructure development for industrial zones and others.

Most of the literature on export incentives is linked to the performance of the exports sector and the factors that influence exports. However, the question of competitiveness between different countries' exporting sectors is not addressed in every respect, particularly in the case of developing countries where these incentives act as a "breather" for the exporting sectors. The issue of export incentives becomes more complex when other countries compete for the same export markets by offering a wide range of export incentives, and also because export incentives have a positive impact on exports while causing the government to lose revenue at the same time.

The range of export incentives offered in India, Pakistan, and Bangladesh is broad. It includes cash incentives, lower income tax rates, concessional export finance, zero-rating sales tax, exemption from export duties, and others. The principal purpose of this paper is to compare the export or fiscal incentives given to the textile industries across these three countries, given that they are also competitors in the international export market. The analysis does not utilize traditional measures that involve export shares or relative prices; rather, we have formulated a novel methodology based on measures of competitiveness at the level of a single firm or individual exporter. The comparative analysis will reveal the 
advantages and disadvantages to Pakistan's textile industry and highlight possible measures to address them.

\section{Export Incentives in Different Countries}

Tax incentives - exceptions to the general tax regime - can be defined as any incentive that reduces the tax burden of an enterprise to induce it to invest particularly in export-oriented projects or sectors. Tax incentives include reduced tax rates on income or profits, tax holidays, allowing accelerated depreciation and loss carry-forwards for the purpose of tax accounting rules, lower tariffs on imported equipment, related components and raw materials, and increased tariffs to protect the domestic market and promote investment in import-substituting projects.

Enhancing exports is one of the main priorities of any government because it is expected to raise the momentum of economic growth and development. In pursuing such goals, governments (particularly in developing countries) have a history of offering generous export incentives to sectors that are considered the mainstay of the economy (see Table 1). Fiscal and nonfiscal export incentives end up being much more than a change in relative prices because they can result in key institutional reforms. For example, if export incentives are provided to a sector characterized by significant economies of scale, there is a higher possibility of demand spillovers from one sector to other sectors. It is even possible that these profitable industries might never have been established otherwise in the first place (Rodrik, 1995).

Within manufacturing in India, Pakistan, and Bangladesh, the textile sectors have a sizeable share in total production, export earnings, employment, and capital formation. Therefore, all three governments have tended to provide various incentives to support their textile sectors through duty exemptions, low tax rates, export finance, and others. In most cases, once granted, the efficacy of these fiscal and nonfiscal incentives is not measured. As a result, any questions concerning a comparison of the value of export incentives in different countries remain unanswered. 


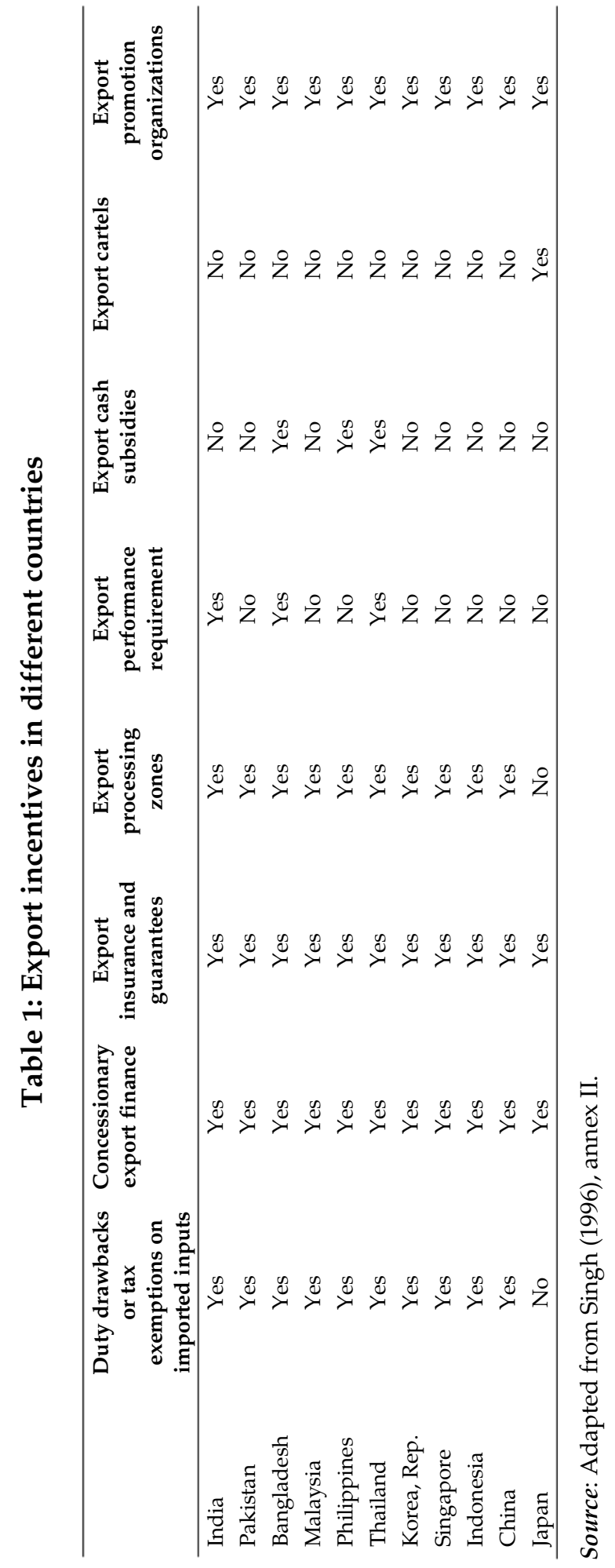




\section{Literature Review}

Export incentives, export promotion, and fiscal incentives to export are an important part of every economy's trade strategy as far as achieving export targets is concerned. These strategies are important to maintain international competitiveness and to increase the productivity of all sectors in general and exporting sectors in particular. However, policies and practices differ across developing and developed countries with respect to their operations and outcomes.

Government strategies to promote exports vary over time and by country according to the needs of exporters and the operation of export systems. India, for example, introduced dramatic policy changes in the 1990s that aimed at improving export performance. Kathuria (1996) examines these policy changes in terms of improvements in export incentives and the elimination of discretionary control in India. The study uses various set-offs and rebates that were provided to exporters in different trade regimes. It compares export profitability across different trade regimes and the difference in domestic and export profitability across the same regimes. The results indicate that export profitability in most export sectors declined under a dual exchange rate regime, while the gap between domestic and export profitability increased because domestic sales were more attractive than export sales. However, this decline in export incentives was reversed under a unified exchange rate regime.

Dholakia, Dholakia, and Kumar (1992) estimate the direct and indirect effects of a unit increase in the demand for exports in terms of gross output, gross value added at factor cost, and the government's net indirect tax revenues. Their analysis of backward and forward linkage coefficients reveals that India's agro-based manufacturing sector needed intensive export promotion as it could generate high incomes without sacrificing its linkage effects to the rest of the economy.

Duty drawback schemes are a major export incentive in all South Asian countries. Mah (2007) examines whether duty drawbacks, which China has used since 1985, have had a significant positive impact on its exports. Applying co-integration tests to an annual dataset for 1979-2001, he finds that duty drawbacks do not promote exports to a significant degree. This may be due to inefficiencies such as false reporting, payment uncertainties, and delayed reimbursement of import duties - all of which are often major problems of the duty drawback system in developing countries. 
A similar study by Haque and Kemal (2007) on Pakistan reveals that rebates or refunds have a small positive impact on exports only in the short run.

In trying to determine the appropriate export promotion strategy, Kinnucan, Duffy, and Ackerman (1995) evaluate the effects of price versus nonprice promotion on US cotton prices, domestic use of cotton, exports of cotton, and the cost of cotton programs. The study suggests that nonprice promotion can be an effective way to reduce government costs of farm programs when the advertising elasticity of export demand is high and the own-price elasticity of demand for exports is relatively low. However, if own-price and advertising demand elasticities vary across regions, selective promotion campaigns are more advisable.

It is now commonly recognized that exchange rate management plays an important role in a country's economic growth. The diverse experience of economic growth among both developed and developing countries shows that any significant overvaluation of the exchange rate should be avoided; this is strongly supported by cross-country evidence from Johnson, Ostry, and Subramanian (2007), Reinhart and Rogoff (2004), and Rajan and Subramanian (2011). Well-known studies by Dollar (1992), Sachs and Warner (1995), and Rodríguez and Rodrik (2001), based on economic growth and outward orientation, concur that degrees of overvaluation affect economic growth and exports negatively.

In Turkey's case, Arslan and van Wijnbergen (1993) find that export incentives and the exchange rate contributed 20 percent to real export growth during 1980-87, where exchange rate depreciation was the most influential factor. Abeysinghe and Yeok (1998) show that exchange rate changes have less impact in the case of exports with a higher content of imported inputs. Services, which have a relatively small imported input content, are affected most by exchange rate changes. Export-oriented manufacturing industries are directly and favorably affected by adjustments in the exchange rate. Thus, while it remains one of the most important components of international competitiveness, exchange rate risk is also associated with the slow growth of export-oriented industries (Zia \& Mahmood, 2013).

\section{Methodology}

There are different indicators of competitiveness at the firm, industry, and national level. Traditional measures use relative export shares, prices, and exchange rates. Of the various concepts and measures, 
however, comparative advantage is the best defined (Siggel, 2007) to the extent of being considered synonymous with competitiveness. Most other measures have macroeconomic interpretations, which are not always an accurate representation of the situation as in the case of comparative advantage or the real effective exchange rate.

Several assumptions are rarely raised when interpreting these measures. For instance, the standard real effective exchange rate is multilateral and assumes that traded goods are final goods (International Monetary Fund, 2013). Therefore, any conclusions based on this measure must state explicitly that it does not apply to trade in intermediate goods, which often account for a significant portion of overall trade. Similarly, most measures of competitiveness assume that the exports of countries or industries are competing in the same markets, which ignores sources of competitive advantage.

\subsection{Evaluation of a Single Export Incentive}

We assume that an individual exporter's sources of competitiveness can include the actual cost of inputs, tax expenditures, the cost of finance, and resource allocation decisions. The relative advantage gained through the magnitude of costs and resource allocation can be (i) the abundance (cheapness) of either primary or intermediate inputs (the extended Heckscher-Ohlin model), (ii) the use of different technology (the Ricardo model), (iii) production on a larger scale (the Krugman model), or (iv) any combination of these sources (Siggel, 2007). The profits earned at the level of the individual exporter and industry reflect these sources of advantage, while export incentives can raise profitability and/or enable exporters to offer foreign buyers better prices, thereby increasing the volume of exports.

One way of valuing an export incentive is to find the exchange rate that would yield the same profit in the absence of the incentive. The higher the resulting exchange rate, the greater is the value of the export incentive. A measure of the equivalent exchange rate can, in this way, be estimated for a single good or industry across different countries competing in the same markets.

The most important factor affecting exports is the cost of production, including the import content and foreign prices the exporter has to face. The exporter's net profit, $\pi_{N}$, is given by 


$$
\pi_{N}=S-C-F-O-T
$$

where $\mathrm{S}=$ sales, $\mathrm{C}=$ the cost of sales, $\mathrm{O}=$ other expenses, $\mathrm{F}=$ financial expenses, and $\mathrm{T}=$ direct tax paid. These are valued in rupees.

$$
C=C_{D}+C_{M}
$$

where $C_{D}$ is the cost of domestic inputs and $C_{M}$ is the cost of imported inputs.

$$
S=S_{X}+S_{D}
$$

where $S_{X}$ refers to export sales and $S_{D}$ to domestic sales.

We analyze two regimes: the first with an export incentive and the actual exchange rate, and the second without the export incentive and the equivalent exchange rate, which equalizes the profit earned under the two regimes. The methodology has been developed for the different export incentives being given to textile exporters in India, Pakistan, and Bangladesh (see Table 2). The firm-level data on Pakistan's textiles sector for the period is from the State Bank of Pakistan. The data on India's textiles sector is from the Economic Times of India and the sample comprises the top five companies (based on their total assets) in each subsector.

Table 2: Major export incentives in the textiles sector

\begin{tabular}{lll}
\hline Pakistan & \multicolumn{1}{c}{ India } & \multicolumn{1}{c}{ Bangladesh } \\
\hline - Lower tax rate on & - Lower tax rate on & - Cash incentives \\
exports & exports & - Lower tax rate on \\
- Concessional export & - Concessional export & exports \\
finance & finance & - Concessional export \\
- Zero rating of & - Duty drawbacks & finance \\
domestic sales & - Tax holiday (SEZs) & - Duty drawbacks \\
& & - Tax holiday (EPZs) \\
\hline
\end{tabular}

\subsection{Evaluation of Different Export Incentives}

In order to analyze the value of each export incentive separately, we determine the equivalent exchange rate in each case using two equations depicting regimes (a) and (b). In each case, the individual exporter's net profit, represented by equation (1), is adjusted to take into account the effect of the export incentive. The detailed methodology for determining the equivalent exchange rate for each incentive is given below. 


\subsubsection{Cash Incentives}

Cash incentives are provided in relation to export proceeds. These are direct disbursements according to the value of exports and, therefore, increase the amount of exports. The equation below illustrates the change in profit under regime (a) in the case of a $c$ percent cash incentive:

$$
\pi_{N}^{a}=S_{X}(1+c \%)+S_{D}-C_{D}-C_{M}-O-\mathrm{F}-\mathrm{T}
$$

where $c$ is the amount of the cash incentive.

The profit equation for regime (b) is as follows:

$$
\pi_{N}^{b}=S_{X} \frac{\varepsilon}{\varepsilon_{0}}+S_{D}-C_{D}-C_{M} \frac{\varepsilon}{\varepsilon_{0}}-O-\mathrm{F}-\mathrm{T}
$$

where $\varepsilon$ is the equivalent exchange rate and $\varepsilon_{o}$ is the actual exchange rate. By equating the profit equation in regimes (a) and (b), we can work out the equivalent exchange rate that has the built-in effect of the cash incentive.

\subsubsection{Presumptive Income Tax}

The presumptive tax is deducted at source and is the full and final discharge of tax liability with respect to all exporters (including companies and registered firms) who have no other receipts and source of income. The tax liability is significantly lower than the income tax liable otherwise. Furthermore, such persons are not required to file the prescribed return of income tax, nor is any formal assessment made. They are only required to furnish a simplified statement of their income and presumptive tax.

For a presumptive income tax of $t_{\mathrm{p}} \%$, the profit model under the two regimes is developed as follows. The net profit before tax under regime (a) will be

$$
\pi_{N}^{a}=S_{X}+S_{D}-C_{D}-C_{M}-F-O
$$

Further, taxes are apportioned into export taxes and domestic taxes. The tax on exports is given by

$T_{X}=\mathrm{t}_{\mathrm{p}} \% \cdot\left(S_{X}\right)$

where $t_{p} \%$ is the rate of presumptive income tax. 
In addition to the presumptive income tax on exports, the exporter must still pay the corporate income tax liable on domestic net profit. In order to measure domestic tax, we need to separate domestic sales from export sales and their relative costs. It is difficult, however, to obtain exact information on how much of the cost of sales, including financial and other expenses, are incurred by domestic sales. We can apportion domestic cost based on the ratio of domestic sales to total sales. The share of domestic cost is written as

$C_{D}=\frac{S_{D}}{S_{X}+S_{D}}(C+O+F)$

Domestic profit before tax $=S_{D}-\left(\frac{S_{D}}{S_{X}+S_{D}}(C+O+F)\right)$

Corporate income tax $=\mathrm{t}_{\mathrm{c}} \% \cdot\left\{S_{D}-\left[\frac{S_{D}}{S_{X}+S_{D}}(C+O+F)\right]\right\}$

where $t_{c} \%$ is the rate of corporate income tax.

Now, the net profit after tax under regime (a) will be

$$
\begin{aligned}
\pi_{N}^{a}=S_{X}+S_{D} & -C_{D}-C_{M}-F-O-\mathrm{t}_{\mathrm{p}} \% \cdot\left(S_{X}\right)-\mathrm{t}_{\mathrm{c}} \% \cdot\left\{S_{D}\right. \\
- & {\left.\left[\frac{S_{D}}{S_{X}+S_{D}}(C+O+F)\right]\right\} }
\end{aligned}
$$

The net profit after tax under regime (b) will be

$$
\pi_{N}^{b}=\left(1-\mathrm{t}_{\mathrm{c}} \%\right)\left(S_{X} \frac{\varepsilon}{\varepsilon_{0}}+S_{D}-C_{D}-C_{M} \frac{\varepsilon}{\varepsilon_{0}}-F-O\right)
$$

Again, we can equate the profit models under both regimes and work out the equivalent exchange rate that includes the built-in effect of the presumptive income tax.

\subsubsection{Concessional Export Finance}

Banks grant concessional finance to exporters on the basis of a firm export order or export letter of credit, for a maximum period of 180 days. The actual incentive would be the difference between the market interest rate and the interest rate on the export finance. It is important to note that the total amount of financing extended by any bank against a firm export order or letter of credit should not exceed the total amount of the firm export order contract or letter of credit. 
The net profit in regime (a) will be

$$
\begin{aligned}
& \pi_{N}^{a}=S_{X}+S_{D}-C_{D}-C_{M}-\left[F-\frac{\left(i_{m}-i_{f}\right) S_{X}}{2}\right]-O-T \\
& \pi_{N}^{a}=S_{X}+S_{D}-C_{D}-C_{M}-\left(F-\frac{\Delta i}{2} \cdot S_{X}\right)-O-T
\end{aligned}
$$

In India's case, where concessional finance is also available for the import of material to be used in exports, the above equation becomes

$$
\pi_{N}^{a}=S_{X}+S_{D}-C_{D}-C_{M}-\left(F-\frac{\Delta i}{2} \cdot S_{X}-\frac{\Delta i}{2} C_{M}\right)-O-T
$$

where $i_{m}$ is the market interest rate, $i_{f}$ is the interest rate in the case of an export finance scheme, and $\Delta i$ is the difference between the market interest rate and the interest rate in the case of an export finance scheme.

The net profit in regime $(b)$ will be

$$
\pi_{N}^{b}=S_{X} \frac{\varepsilon}{\varepsilon_{0}}+S_{D}-C_{D}-C_{M} \frac{\varepsilon}{\varepsilon_{0}}-F-O-T
$$

\subsubsection{Zero Rating of Domestic Sales}

Zero-rating domestic sales enables exporters, manufacturers, and suppliers to adjust the tax paid on inputs incurred with that of output tax. Producers are allowed to avail this incentive if they are also exporters. When producers have incentive to enter the international market, this increases the exports of the overall industry. Moreover, entering the international market makes them more competitive as their overall cost of production falls. The impact of zero-rated domestic sales is incorporated via the effective tax rate $\left(\tau_{e}\right)$.

The net profit model is

$$
\pi_{N}^{a}=S_{X}+S_{D}-C_{D}-C_{M}-F-O-T
$$

Zero-rating domestic sales such that $\mathrm{T}=0$ in regime (a) would yield the following form:

$$
\pi_{N}^{a}=S_{X}+S_{D}-C_{D}-C_{M}-F-O+\tau_{e} \cdot S_{D}
$$

The net profit equation in regime (b) is 


$$
\pi_{N}^{b}=S_{X} \frac{\varepsilon}{\varepsilon_{0}}+S_{D}-C_{D}-C_{M} \frac{\varepsilon}{\varepsilon_{0}}-F-O
$$

Sales tax in the case of Pakistan is a value-added tax and, therefore, the input tax (on inputs/the cost of goods sold) is deducted from the output tax (on output/sales) to yield the net sales tax payable. The input and output tax rate $\left(t_{v a t}\right)$ is the same, but in the case of zero-rated sales, the output tax is charged at 0 percent and the taxpayer is entitled to claim the input tax. The true value of the incentive thus depends on the value addition: the higher the value addition, the higher will be the incentive. In this case, the effective tax rate $\left(\tau_{e}\right)$ on sales is as follows:

Value added $=$ sales - cost of goods sold 1

Net tax payable $=t_{\text {vat }}$. value added

where $t_{v a t}$ is the rate of value-added tax.

The effective tax rate on sales is $\tau_{e}=\frac{t_{\text {vat }} \times \text { value added }}{\text { sales }}$

\subsubsection{Duty Drawbacks}

A duty drawback means that, if any duty is paid on the import of goods subsequently used to produce other goods for export, the amount paid as duty on that import will be credited to the exporter.

The profit equation in regime (a) is as follows:

$$
\pi_{N}^{a}=S_{X}+D \cdot\left(\frac{C_{M}}{S_{X}} \%\right)+S_{D}-C_{D}-C_{M}-F-O-T
$$

where the duty drawback $D \cdot\left(\frac{C_{M}}{S_{X}} \%\right)=$ (the estimated import duties paid for one year) $x$ (percentage of import components in exported articles).

The net profit equation in regime (b) will be

$$
\pi_{N}^{a}=S_{X} \frac{\varepsilon}{\varepsilon_{0}}+S_{D}-C_{D}-C_{M} \frac{\varepsilon}{\varepsilon_{0}}-F-O-T
$$

\footnotetext{
${ }^{1}$ The term "cost of goods sold" does not include financial and other costs, but comprises primarily material inputs and labor that are directly associated with the production of the good.
} 


\subsubsection{Tax Holiday}

In the case of a tax holiday, the exporter need not pay any tax. In India, for example, all industrial units located in special economic zones and export promotion zones are allowed a five-year tax holiday. They can also import goods free of import duty. In such a case, the equation for regime (a) would take the following form:

$$
\pi_{N}^{a}=S_{X}+S_{D}-C_{D}-C_{M}+F-O
$$

The net profit equation in regime $(b)$ would be

$$
\pi_{N}^{b}=S_{X} \frac{\varepsilon}{\varepsilon_{0}}+S_{D}-C_{D}-C_{M} \frac{\varepsilon}{\varepsilon_{0}}-F-O-T
$$

\section{Results and Discussion}

The value of an export incentive is calculated in terms of the equivalent exchange rate for made-up textiles, other textiles, and spun, woven, and finished textiles. The difference between the equivalent and actual exchange rates in the case of a particular subsidy indicates the amount of subsidy against US\$ 1 of exports.

The total value of export incentives is the aggregate of the value of different export incentives (see Appendix), some of which are the same in Pakistan, India, and Bangladesh (Table 2). However, the value of similar export incentives is different in each country because of different tax rates, interest rates on concessionary export finance, and duty drawbacks as well as the underlying structure of that country's textiles industry. Comparing the subsidies offered to the three sectors enables us to identify the relative size of overall subsidies given to the textiles sectors in these countries. It also reveals whether the magnitude of these subsidies has risen over time (Table 3). 
Table 3: Total value of export incentives in Pakistan

\begin{tabular}{lrrrrr} 
& \multicolumn{1}{c}{} & & (PRs/\$) \\
\hline Category & $\mathbf{2 0 0 1}$ & $\mathbf{2 0 0 5}$ & $\mathbf{2 0 0 9}$ & $\mathbf{2 0 1 0}$ & $\mathbf{2 0 1 1}$ \\
\hline Made-up textiles & & & & & \\
Equivalent exchange rate & 71.6 & 72.8 & 94.4 & 102.2 & 103.9 \\
Actual exchange rate & 58.4 & 59.4 & 78.5 & 83.8 & 85.5 \\
Difference & 13.2 & 13.4 & 15.9 & 18.4 & 18.4 \\
Percentage change & 22.6 & 22.6 & 20.3 & 22.0 & 21.5 \\
Other textiles & & & & & \\
Equivalent exchange rate & 70.8 & 71.5 & 92.3 & 97.1 & 105.8 \\
Actual exchange rate & 58.4 & 59.4 & 78.5 & 83.8 & 85.5 \\
Difference & 12.4 & 12.1 & 13.8 & 13.3 & 20.3 \\
Percentage change & 21.2 & 20.4 & 17.6 & 15.9 & 23.7 \\
Spinning, weaving and finishing & & & & & \\
Equivalent exchange rate & 62.4 & 67.4 & 85.4 & 95.4 & 96.4 \\
Actual exchange rate & 58.4 & 59.4 & 78.5 & 83.8 & 85.5 \\
Difference & 4.0 & 8.0 & 6.9 & 11.6 & 10.9 \\
Percentage change & 6.8 & 13.5 & 8.8 & 13.8 & 12.7 \\
\hline
\end{tabular}

Source: Author's calculations.

In Pakistan, the value of major government subsidies was PRs 18.4 per dollar of exports in 2011 for made-up textiles alone, having increased from PRs 13.2 per dollar in 2001. The percentage increase in the equivalent exchange rate indicates that it was about 22 percent higher than the actual exchange rate for made-up textiles. Other textiles have enjoyed subsidies of almost the same magnitude. The value of the subsidy for spun, woven, and finished textiles is smaller than that of made-up and other textiles: it was PRs 4 per dollar of exports in 2001 and increased to PRs 10.9 per dollar in 2011. The equivalent exchange rate for this subsector is 12.7 percent higher than the actual exchange rate.

In India, the equivalent exchange rate for the spinning, weaving, and finishing subsector increased to 37.2 percent in 2001 and to 70 percent higher than the actual exchange rate in 2011. The equivalent exchange rate increased to 52 and 44.9 percent higher than the actual exchange rate for made-up and other textiles, respectively. The value of export incentives in India is, therefore, far higher than in Pakistan (Table 4). 
Table 4: Total value of export incentives in India

\begin{tabular}{|c|c|c|c|c|c|}
\hline Category & 2001 & 2005 & 2009 & 2010 & 2011 \\
\hline \multicolumn{6}{|l|}{ Made-up textiles } \\
\hline Equivalent exchange rate & 71.51 & 65.37 & 68.41 & 71.45 & 71.87 \\
\hline Actual exchange rate & 46.70 & 41.30 & 46.60 & 48.60 & 47.20 \\
\hline Difference & 24.81 & 24.07 & 21.81 & 22.85 & 24.67 \\
\hline Percentage change & 53.10 & 58.30 & 46.80 & 47.00 & 52.30 \\
\hline \multicolumn{6}{|l|}{ Other textiles } \\
\hline Equivalent exchange rate & 70.04 & 54.80 & 66.31 & 71.12 & 68.40 \\
\hline Actual exchange rate & 46.70 & 41.30 & 46.60 & 48.60 & 47.20 \\
\hline Difference & 23.34 & 13.50 & 19.71 & 22.52 & 21.20 \\
\hline Percentage change & 50.00 & 32.70 & 42.30 & 46.30 & 44.90 \\
\hline \multicolumn{6}{|c|}{ Spinning, weaving and finishing } \\
\hline Equivalent exchange rate & 64.06 & 53.63 & 67.04 & 78.99 & 80.24 \\
\hline Actual exchange rate & 46.70 & 41.30 & 46.60 & 48.60 & 47.20 \\
\hline Difference & 17.36 & 12.33 & 20.44 & 30.39 & 33.04 \\
\hline Percentage change & 37.20 & 29.90 & 43.90 & 62.50 & 70.00 \\
\hline
\end{tabular}

Source: Author's calculations.

One way of comparing export incentives in India and Pakistan is to apply Indian export incentives to Pakistan's structure of textiles (Table 5). In this way, the equivalent exchange rate that builds in the impact of Indian export incentives (in Pakistan) can be compared to the equivalent exchange rate that builds in Pakistan's own export incentives. For 2011, the equivalent exchange rate incorporating Indian export incentives for madeup textiles increases to PRs 106.69, which is 24.8 percent higher than the actual exchange rate; it is 21.5 percent higher when Pakistani export incentives are applied for the same period.

For 2011, the equivalent exchange rate increases by 31 and 17 percent, respectively, for other textiles and for spun, woven, and finished textiles compared to 23.7 and 12 percent when Pakistani export incentives are applied. Given that the structure of Pakistan's textiles sector is different from that of India, were we to apply Indian export incentives (with the same rates) to Pakistan's textiles sector, the resulting equivalent exchange rate would also be different from that of India.

Similarly, for 2011, the equivalent exchange rate for made-up textiles that builds in Bangladesh's export incentives increases by 37.5 percent compared to 21.5 percent in the case of Pakistan's own export incentives (Table 6). The equivalent exchange rate that Pakistani exporters would face in other textiles and in the spinning, weaving, and finishing 
subsector, given Bangladesh's export incentives, increases by 45.9 and 27 percent, respectively, compared to 23.7 and 12.7 percent when Pakistan's own export incentives are applied.

Table 5: Total value of export incentives when Indian export incentives are extended to Pakistani textiles*

\begin{tabular}{lrrrrr} 
& & & & & $(\mathrm{Rs} / \$)$ \\
\hline Category & $\mathbf{2 0 0 1}$ & $\mathbf{2 0 0 5}$ & $\mathbf{2 0 0 9}$ & $\mathbf{2 0 1 0}$ & $\mathbf{2 0 1 1}$ \\
\hline Made-up textiles & & & & & \\
Equivalent exchange rate & 73.06 & 75.66 & 97.77 & 106.39 & 106.69 \\
Actual exchange rate & 58.40 & 59.40 & 78.50 & 83.80 & 85.50 \\
Difference & 14.66 & 16.26 & 19.27 & 22.59 & 21.19 \\
$\begin{array}{l}\text { Percentage change } \\
\text { Other textiles }\end{array}$ & 25.10 & 27.40 & 24.50 & 27.00 & 24.80 \\
$\begin{array}{l}\text { Equivalent exchange rate } \\
\text { Actual exchange rate }\end{array}$ & 81.98 & 73.73 & 93.00 & 102.18 & 112.02 \\
Difference & 58.40 & 59.40 & 78.50 & 83.80 & 85.50 \\
$\begin{array}{l}\text { Percentage change } \\
\text { Spinning, weaving and finishing }\end{array}$ & 23.58 & 14.33 & 14.50 & 18.38 & 26.52 \\
Equivalent exchange rate & 40.40 & 24.10 & 18.50 & 21.90 & 31.00 \\
Actual exchange rate & 61.08 & 70.50 & 84.25 & 98.11 & 100.73 \\
Difference & 58.40 & 59.40 & 78.50 & 83.80 & 85.50 \\
Percentage change & 2.68 & 11.10 & 5.75 & 14.31 & 15.23 \\
\hline
\end{tabular}

Source: Author's calculations.

Table 6: Total value of export incentives when Bangladesh's export incentives are extended to Pakistani textiles

\begin{tabular}{|c|c|c|c|c|c|}
\hline Category & 2001 & 2005 & 2009 & 2010 & 2011 \\
\hline \multicolumn{6}{|l|}{ Made-up textiles } \\
\hline Equivalent exchange rate & 80.2 & 82.9 & 107.2 & 116.7 & 117.5 \\
\hline Actual exchange rate & 58.4 & 59.4 & 78.5 & 83.8 & 85.5 \\
\hline Difference & 21.8 & 23.5 & 28.7 & 32.9 & 32.0 \\
\hline Percentage change & 37.3 & 39.6 & 36.6 & 39.3 & 37.5 \\
\hline \multicolumn{6}{|l|}{ Other textiles } \\
\hline Equivalent exchange rate & 93.3 & 82.7 & 103.4 & 113.4 & 124.7 \\
\hline Actual exchange rate & 58.4 & 59.4 & 78.5 & 83.8 & 85.5 \\
\hline Difference & 34.9 & 23.3 & 24.9 & 29.6 & 39.2 \\
\hline Percentage change & 59.7 & 39.2 & 31.8 & 35.3 & 45.9 \\
\hline \multicolumn{6}{|c|}{ Spinning, weaving and finishing } \\
\hline Equivalent exchange rate & 70.4 & 76.1 & 95.7 & 106.1 & 108.6 \\
\hline Actual exchange rate & 58.4 & 59.4 & 78.5 & 83.8 & 85.5 \\
\hline Difference & 12.0 & 16.7 & 17.2 & 22.3 & 23.1 \\
\hline Percentage change & 20.6 & 28.1 & 21.9 & 26.7 & 27.0 \\
\hline
\end{tabular}

Source: Author's calculations. 


\section{Conclusion and Policy Recommendations}

This study has highlighted the major export incentives used to boost export growth. The comparative analysis evaluates individual export incentives in terms of the equivalent exchange rate offered to the textiles sector, which accounts for 87,53 , and 11 percent of exports for Bangladesh, Pakistan, and India, respectively. The results indicate that Bangladesh's textiles sector is the most export-oriented of the three.

The impact of export incentives is highest for Bangladesh's textiles sector. When the same export incentives are applied to the Pakistani textiles sector, the equivalent exchange rates for 2011 are 37.5, 45.9, and 27 percent for made-up textiles, other textiles, and spun, woven, and finished textile exports, respectively. In comparison, the impact of Indian export incentives, when applied to Pakistani textiles, raises the equivalent exchange rate to $24.8,31$, and 17 percent for made-up textiles, other textiles, and spun, woven, and finished textile exports, respectively. The impact of Pakistan's own export incentives on its textiles sector is considerably lower: the equivalent exchange rate rises by 21.5, 23.7, and 12.7 percent for made-up textiles, other textiles, and spun, woven, and finished textile exports, respectively.

Considering the importance of the textiles industry to the country's overall economic health, Pakistan needs to revisit its trade policy for this sector. Over the last few years, the textiles industry has become trapped by severe challenges at home as well as abroad because of increasingly competitive international prices. Pakistan's textiles industry has begun to shift to India and Bangladesh in the face of rising crises, the main reason being the latter's fairly liberal export incentive schemes.

The comparative evaluation of export incentives suggests that Pakistan needs far more liberal export incentives for textiles if it is to compete with its neighbors. This does not necessarily mean that it should match the number and type of incentives given by Bangladesh and India. Whatever incentives the government chooses to offer and structure, it should ensure that (i) the foregone income does not severely undermine government revenues, (ii) the incentives are easily accessible, and (iii) eligibility for these incentives is easily determined.

The following are some key policy implications, with particular reference to Pakistan: 
Currently, Pakistan's export incentives scheme is far less liberal compared to India and Bangladesh. Based on our analysis of export incentives, Bangladesh is more competitive than its regional neighbors. However, many other factors also affect competitiveness, including free trade agreements and other export promotion strategies. Given the existing structure of the textiles industry in each of these countries, our analysis suggests that Pakistan needs to enhance its export incentives, particularly for value-added textiles.

Also, export incentives may be preferable to a general depreciation of the exchange rate, which would otherwise increase the prices of essential imports to the detriment of poorer households.

Finally Pakistan needs to rationalize its export incentives regime with a large number of small incentives, even if these incur high transaction costs. This could be done, first, by reducing the presumptive income tax, particularly on value-added textiles, and by eliminating the export development surcharge. A second step could be to provide export cash assistance in lieu of duty drawbacks, R\&D subsidies, freight subsidies, and higher energy prices similar to Bangladesh, where cash assistance rates vary from 5 to 25 percent of export proceeds, with the highest rates for export-oriented sectors. 


\section{References}

Abeysinghe, T., \& Yeok, T. L. (1998). Exchange rate appreciation and export competitiveness: The case of Singapore. Applied Economics, 30(1), $51-55$.

Arslan, I., \& van Wijnbergen, S. (1993). Export incentives, exchange rate policy and export growth in Turkey. Review of Economics and Statistics, 75(1), 128-133.

Dholakia, R. H., Dholakia, B. H., \& Kumar, G. (1992). Issues in strategy for export promotion: An inter-industry analysis. Economic and Political Weekly, 27(48), M149-M155.

Dollar, D. (1992). Outward-oriented developing economies really do grow more rapidly: Evidence from 95 LCDs, 1976-85. Economic Development and Cultural Change, 40(3), 523-544.

Fox, W. F., \& Murray, M. N. (2004). Do economic effects justify the use of fiscal incentives? Southern Economic Journal, 71(1), 78-92.

Francis, J., \& Collins-Dodd, C. (2004). Impact of export promotion programs on firm competencies, strategies and performance: The case of Canadian high-technology SMEs. International Marketing Review, 21(4/5), 474-495.

Haque, N. \& Kemal, M. A. (2007). Impact of export subsidies on Pakistan's exports (Working Paper No. 26). Islamabad: Pakistan Institute of Development Economics.

International Monetary Fund. (2013). Trade interconnectedness: The world with global value chains. Retrieved from http://www.imf.org/external/np/pp/eng/2013/082613.pdf

Johnson, S., Ostry, J. D., \& Subramanian, A. (2007). The prospects for sustained growth in Africa: Benchmarking the constraints (Working Paper No. 13120). Washington, DC: National Bureau of Economic Research.

Kathuria, S. (1996). Export incentives: The impact of recent policy changes in India. Indian Economic Review, 31(1), 109-126. 
Kinnucan, H. W., Duffy, P. A., \& Ackerman, K. Z. (1995). Effects of price versus non-price export promotion: The case of cotton. Review of Agricultural Economics, 17(1), 91-100.

Lederman, D., Olarreaga, M., \& Payton, L. (2006). Export promotion agencies: What works and what does not (Trade Note No. 30). Washington, DC: World Bank.

Mah, J. S. (2007). Duty drawback and export promotion in China. Journal of Developing Areas, 40(2), 133-140.

Martincus, C. V., \& Carballo, J. (2008). Is export promotion effective in developing countries? Firm-level evidence on the intensive and the extensive margins of exports. Journal of International Economics, 76, 89-106.

Martincus, C. V., \& Carballo, J. (2010). Entering new country and product markets: Does export promotion help? Review of World Economics, 146(3), 437-467.

Naidu, G. M., Cavusgil, S. T., Murthy, B. K., \& Sarkar, M. (1997). An export promotion model for India: Implications for public policy. International Business Review, 6(2), 113-125.

Rajan, R. G., \& Subramanian, A. (2011). Aid, Dutch disease, and manufacturing growth. Journal of Development Economics, 94(1), 106118.

Reinhart, C. M., \& Rogoff, K. S. (2004). The modern history of exchange rate arrangements: A reinterpretation. Quarterly Journal of Economics, 119(1), 1-48.

Rodrik, D. (1995). Trade and industrial policy reform. In J. Behrman \& T. N. Srinivasan (Eds.), Handbook of development economics (vol. 3B, pp. 2927-2964). Philadelphia, PA: Elsevier.

Rodríguez, F., \& Rodrik, D. (2001). Trade policy and economic growth: A skeptic's guide to the cross-national evidence. NBER Macroeconomics Annual 2000, 15, 261-338.

Sachs, J. D., \& Warner, A. (1995). Economic reform and the process of global integration. Brookings Papers on Economic Activity, 26, 1-118. 
Seringhaus, F. H. R., \& Botschen, G. (1991). Cross-national comparison of export promotion services: The views of Canadian and Austrian companies. Journal of International Business Studies, 22(1), 115-133.

Siggel, E. (2007, July). International competitiveness and comparative advantage: A survey and a proposal for measurement. Paper presented at the CESifo Venice Summer Institute, Italy.

Singh, A. (1996). The post-Uruguay Round world trading system, industrialization, trade and development: Implications for the Asia-Pacific developing countries. In Expansion of trading opportunities to the year 2000 for Asia-Pacific developing countries: Implications of the Uruguay Round and adaption of export strategies (pp. 147-190). Geneva: UNCTAD.

Togan, S. (1993). How to assess the significance of export incentives: An application to Turkey. Weltwirtschaftliches Archiv, 129(4), 777-800.

Zia, U., \& Mahmood, Z. (2013). Exchange rate depreciation and export price competitiveness: The case of Pakistani manufacturing industries. Journal of the Asia Pacific Economy, 18(4), 529-542. 


\section{Appendix}

\section{Value of export incentives in Pakistan}

Table A1: Estimated equivalent exchange rate for presumptive income tax

\begin{tabular}{lrrrrr} 
& \multicolumn{1}{c}{} & & (Rs/\$) \\
\hline Category & $\mathbf{2 0 0 0 / 0 1}$ & $\mathbf{2 0 0 4 / 0 5}$ & $\mathbf{2 0 0 8 / 0 9}$ & $\mathbf{2 0 0 9 / 1 0}$ & $\mathbf{2 0 1 0 / 1 1}$ \\
\hline Made-up textiles & & & & & \\
Equivalent exchange rate & 66.9 & 69.2 & 89.2 & 96.6 & 96.7 \\
Actual exchange rate & 58.4 & 59.4 & 78.5 & 83.8 & 85.5 \\
Difference & 8.5 & 9.8 & 10.7 & 12.8 & 11.2 \\
Percentage change & 14.6 & 16.5 & 13.6 & 15.3 & 13.1 \\
Other textiles & & & & & \\
Equivalent exchange rate & 63.6 & 64.1 & 83.5 & 87.9 & 93.3 \\
Actual exchange rate & 58.4 & 59.4 & 78.5 & 83.8 & 85.5 \\
Difference & 5.2 & 4.8 & 5.0 & 4.1 & 7.8 \\
Percentage change & 8.9 & 8.1 & 6.4 & 4.9 & 9.1 \\
Spinning, weaving and finishing & & & & & \\
Equivalent exchange rate & 59.1 & 64.0 & 80.5 & 89.9 & 92.0 \\
Actual exchange rate & 58.4 & 59.4 & 78.5 & 83.8 & 85.5 \\
Difference & 0.6 & 4.7 & 2.0 & 6.1 & 6.5 \\
Percentage change & 1.0 & 7.9 & 2.5 & 7.3 & 7.6 \\
\hline
\end{tabular}

Note: $t c=15 \%, t p=1 \%$.

Source: Author's calculations. 
Table A2: Estimated equivalent exchange rate for concessionary export finance

\begin{tabular}{lrrrrr} 
& \multicolumn{1}{c}{} & & $(\mathrm{Rs} / \mathbf{\$})$ \\
\hline Category & $\mathbf{2 0 0 0 / 0 1}$ & $\mathbf{2 0 0 4 / 0 5}$ & $\mathbf{2 0 0 8 / 0 9}$ & $\mathbf{2 0 0 9 / 1 0}$ & $\mathbf{2 0 1 0 / 1 1}$ \\
\hline Made-up textiles & & & & & \\
Equivalent exchange rate & 59.1 & 60.1 & 79.4 & 84.8 & 86.6 \\
Actual exchange rate & 58.4 & 59.4 & 78.5 & 83.8 & 85.5 \\
Difference & 0.7 & 0.7 & 1.0 & 1.0 & 1.1 \\
Percentage change & 1.2 & 1.2 & 1.3 & 1.2 & 1.3 \\
Other textiles & & & & & \\
Equivalent exchange rate & 59.6 & 60.2 & 79.5 & 84.9 & 86.8 \\
Actual exchange rate & 58.4 & 59.4 & 78.5 & 83.8 & 85.5 \\
Difference & 1.1 & 0.9 & 1.0 & 1.1 & 1.3 \\
Percentage change & 1.9 & 1.5 & 1.3 & 1.3 & 1.5 \\
Spinning, weaving and finishing & & & & & \\
Equivalent exchange rate & 59.1 & 60.0 & 79.4 & 84.7 & 86.5 \\
Actual exchange rate & 58.4 & 59.4 & 78.5 & 83.8 & 85.5 \\
Difference & 0.7 & 0.7 & 0.9 & 0.9 & 1.0 \\
Percentage change & 1.2 & 1.2 & 1.1 & 1.1 & 1.2 \\
\hline
\end{tabular}

Note: The difference between the market interest rate and interest rate on export finance is fixed at 2 percent.

Source: Author's calculations.

Table A3: Estimated equivalent exchange rate for zero-rated domestic sales

\begin{tabular}{lrrrrr} 
& & & & & $(\mathrm{Rs} / \$)$ \\
\hline Category & $\mathbf{2 0 0 0 / 0 1}$ & $\mathbf{2 0 0 4 / 0 5}$ & $\mathbf{2 0 0 8 / 0 9}$ & $\mathbf{2 0 0 9 / 1 0}$ & $\mathbf{2 0 1 0 / 1 1}$ \\
\hline Made-up textiles & & & & & \\
Equivalent exchange rate & 62.5 & 62.2 & 82.7 & 88.4 & 91.6 \\
Actual exchange rate & 58.4 & 59.4 & 78.5 & 83.8 & 85.5 \\
Difference & 4.0 & 2.9 & 4.2 & 4.6 & 6.1 \\
Percentage change & 6.8 & 4.9 & 5.4 & 5.5 & 7.1 \\
Other textiles & & & & & \\
Equivalent exchange rate & 64.5 & 65.8 & 86.3 & 91.9 & 96.7 \\
Actual exchange rate & 58.4 & 59.4 & 78.5 & 83.8 & 85.5 \\
Difference & 6.1 & 6.4 & 7.8 & 8.1 & 11.2 \\
Percentage change & 10.4 & 10.8 & 9.9 & 9.7 & 13.1 \\
Spinning, weaving and finishing & & & & & \\
Equivalent exchange rate & 61.1 & 61.9 & 82.5 & 88.4 & 88.9 \\
Actual exchange rate & 58.4 & 59.4 & 78.5 & 83.8 & 85.5 \\
Difference & 2.7 & 2.6 & 4.0 & 4.6 & 3.4 \\
Percentage change & 4.6 & 4.4 & 5.1 & 5.5 & 4.0 \\
\hline
\end{tabular}

Source: Author's calculations. 


\section{Value of export incentives in India}

Table A4: Estimated equivalent exchange rate for zero-rated exports

\begin{tabular}{lrrrrr} 
& & & & & $(\mathrm{Rs} / \$)$ \\
\hline Category & $\mathbf{2 0 0 0 / 0 1}$ & $\mathbf{2 0 0 4 / 0 5}$ & $\mathbf{2 0 0 8 / 0 9}$ & $\mathbf{2 0 0 9 / 1 0}$ & $\mathbf{2 0 1 0 / 1 1}$ \\
\hline Made-up textiles & & & & & \\
Equivalent exchange rate & 66.48 & 55.22 & 59.29 & 61.06 & 59.95 \\
Actual exchange rate & 46.67 & 41.35 & 46.58 & 48.61 & 47.19 \\
Difference & 19.81 & 13.87 & 12.71 & 12.45 & 12.77 \\
Percentage change & 42.40 & 33.50 & 27.30 & 25.60 & 27.10 \\
Other textiles & & & & & \\
Equivalent exchange rate & 64.81 & 48.65 & 58.19 & 61.53 & 58.09 \\
Actual exchange rate & 46.67 & 41.35 & 46.58 & 48.61 & 47.19 \\
Difference & 18.14 & 7.30 & 11.61 & 12.92 & 10.90 \\
Percentage change & 38.90 & 17.70 & 24.90 & 26.60 & 23.10 \\
Spinning, weaving and finishing & & & & & \\
Equivalent exchange rate & 61.33 & 48.68 & 63.22 & 72.20 & 70.93 \\
Actual exchange rate & 46.67 & 41.35 & 46.58 & 48.61 & 47.18 \\
Difference & 14.66 & 7.33 & 16.64 & 23.59 & 23.74 \\
Percentage change & 31.40 & 17.70 & 35.70 & 48.50 & 50.30 \\
\hline
\end{tabular}

Note: Exports are zero-rated and credit is available on input tax.

Source: Author's calculations.

Table A5: Estimated equivalent exchange rate for tax holiday

(Rs/\$)

\begin{tabular}{lrrrrr}
\hline Category & $\mathbf{2 0 0 0 / 0 1}$ & $\mathbf{2 0 0 4 / 0 5}$ & $\mathbf{2 0 0 8 / 0 9}$ & $\mathbf{2 0 0 9 / 1 0}$ & $\mathbf{2 0 1 0 / 1 1}$ \\
\hline Made-up textiles & & & & & \\
Equivalent exchange rate & 47.1 & 44.6 & 49.2 & 54.8 & 54.0 \\
Actual exchange rate & 46.7 & 41.3 & 45.3 & 48.6 & 47.2 \\
Difference & 0.5 & 3.3 & 3.9 & 6.1 & 6.9 \\
Percentage change & 1.0 & 7.9 & 8.6 & 12.6 & 14.5 \\
Other textiles & & & & & \\
Equivalent exchange rate & 47.1 & 44.6 & 50.9 & 54.8 & 54.0 \\
Actual exchange rate & 46.7 & 41.3 & 46.6 & 48.6 & 47.2 \\
Difference & 0.5 & 3.3 & 4.4 & 6.1 & 6.9 \\
Percentage change & 1.1 & 8.0 & 9.4 & 12.6 & 14.6 \\
Spinning, weaving and finishing & & & & & \\
Equivalent exchange rate & 46.8 & 43.3 & 47.8 & 51.5 & 51.8 \\
Actual exchange rate & 46.7 & 41.3 & 46.6 & 48.6 & 47.2 \\
Difference & 0.1 & 2.0 & 1.2 & 2.9 & 4.6 \\
Percentage change & 0.2 & 4.8 & 2.6 & 6.0 & 9.7 \\
\hline
\end{tabular}

Source: Author's calculations. 
Table A6: Estimated equivalent exchange rate for duty drawbacks

\begin{tabular}{lrrrrr} 
& & & & & $(\mathrm{Rs} / \mathbf{\$})$ \\
\hline Category & $\mathbf{2 0 0 0 / 0 1}$ & $\mathbf{2 0 0 4 / 0 5}$ & $\mathbf{2 0 0 8 / 0 9}$ & $\mathbf{2 0 0 9 / 1 0}$ & $\mathbf{2 0 1 0 / 1 1}$ \\
\hline Made-up textiles & & & & & \\
Equivalent exchange rate & 48.3 & 42.4 & 47.3 & 49.2 & 48.1 \\
Actual exchange rate & 46.7 & 41.3 & 46.6 & 48.6 & 47.2 \\
Difference & 1.6 & 1.0 & 0.7 & 0.6 & 0.9 \\
Percentage change & 3.4 & 2.4 & 1.5 & 1.2 & 1.9 \\
Other textiles & & & & & \\
Equivalent exchange rate & 47.9 & 41.9 & 47.3 & 49.0 & 47.7 \\
Actual exchange rate & 46.7 & 41.3 & 46.6 & 48.6 & 47.2 \\
Difference & 1.2 & 0.6 & 0.7 & 0.4 & 0.5 \\
Percentage change & 2.6 & 1.5 & 1.5 & 0.8 & 1.1 \\
Spinning, weaving and finishing & & & & & \\
Equivalent exchange rate & 47.6 & 42.4 & 46.9 & 49.0 & 47.8 \\
Actual exchange rate & 46.7 & 41.3 & 46.6 & 48.6 & 47.2 \\
Difference & 0.9 & 1.1 & 0.3 & 0.4 & 0.6 \\
Percentage change & 1.9 & 2.7 & 0.6 & 0.8 & 1.3 \\
\hline
\end{tabular}

Note: Duty drawback for te0xtiles is fixed at 10 percent.

Source: Author's calculations.

Table A7: Estimated equivalent exchange rate for concessional export finance

$(\mathrm{Rs} / \$)$

\begin{tabular}{lrrrrr}
\hline Category & $\mathbf{2 0 0 0 / 0 1}$ & $\mathbf{2 0 0 4 / 0 5}$ & $\mathbf{2 0 0 8 / 0 9}$ & $\mathbf{2 0 0 9 / 1 0}$ & $\mathbf{2 0 1 0 / 1 1}$ \\
\hline Made-up textiles & & & & & \\
Equivalent exchange rate & 49.6 & 47.3 & 50.6 & 52.3 & 51.3 \\
Actual exchange rate & 46.7 & 41.3 & 46.6 & 48.6 & 47.2 \\
Difference & 2.9 & 5.9 & 4.0 & 3.7 & 4.1 \\
Percentage change & 6.2 & 14.3 & 8.6 & 7.6 & 8.7 \\
Other textiles & & & & & \\
Equivalent exchange rate & 50.1 & 43.7 & 49.6 & 51.7 & 50.0 \\
Actual exchange rate & 46.7 & 41.3 & 46.6 & 48.6 & 47.2 \\
Difference & 3.5 & 2.3 & 3.0 & 3.1 & 2.9 \\
Percentage change & 7.5 & 5.6 & 6.4 & 6.4 & 6.1 \\
Spinning, weaving and finishing & & & & & \\
Equivalent exchange rate & 48.4 & 43.2 & 48.9 & 52.2 & 51.2 \\
Actual exchange rate & 46.7 & 41.3 & 46.6 & 48.6 & 47.2 \\
Difference & 1.7 & 1.9 & 2.3 & 3.5 & 4.1 \\
Percentage change & 3.6 & 4.6 & 4.9 & 7.2 & 8.7 \\
\hline
\end{tabular}

Note: The difference between the market interest rate and interest rate on export finance is fixed at 2.5 percent.

Source: Author's calculations. 


\section{Bangladesh's export incentives applied to structure of Pakistani textiles}

Table A8: Estimated equivalent exchange rate for cash incentive

\begin{tabular}{lrrrrr} 
& & & & & $(\mathrm{Rs} / \mathbf{\$})$ \\
\hline Category & $\mathbf{2 0 0 0 / 0 1}$ & $\mathbf{2 0 0 4 / 0 5}$ & $\mathbf{2 0 0 8 / 0 9}$ & $\mathbf{2 0 0 9 / 1 0}$ & $\mathbf{2 0 1 0 / 1 1}$ \\
\hline Made-up textiles & & & & & \\
Equivalent exchange rate & 69.0 & 70.2 & 92.8 & 99.3 & 101.7 \\
Actual exchange rate & 58.4 & 59.4 & 78.5 & 83.8 & 85.5 \\
Difference & 10.6 & 10.9 & 14.3 & 15.5 & 16.2 \\
Percentage change & 18.1 & 18.3 & 18.2 & 18.5 & 19.0 \\
Other textiles & & & & & \\
Equivalent exchange rate & 75.3 & 72.7 & 94.1 & 100.6 & 104.6 \\
Actual exchange rate & 58.4 & 59.4 & 78.5 & 83.8 & 85.5 \\
Difference & 16.9 & 13.3 & 15.6 & 16.8 & 19.1 \\
Percentage change & 28.9 & 22.5 & 19.9 & 20.1 & 22.3 \\
Spinning, weaving and finishing & & & & & \\
Equivalent exchange rate & 68.4 & 69.7 & 92.0 & 97.9 & 99.9 \\
Actual exchange rate & 58.4 & 59.4 & 78.5 & 83.8 & 85.5 \\
Difference & 9.9 & 10.3 & 13.5 & 14.1 & 14.4 \\
Percentage change & 17.0 & 17.3 & 17.1 & 16.9 & 16.8 \\
\hline
\end{tabular}

Note: Cash incentive $=5$ percent of export proceeds.

Source: Author's calculations.

Table A9: Estimated equivalent exchange rate for exempted exports

\begin{tabular}{lrrrrr} 
& & & & & (Rs/\$) \\
\hline Category & $\mathbf{2 0 0 0 / 0 1}$ & $\mathbf{2 0 0 4 / 0 5}$ & $\mathbf{2 0 0 8 / 0 9}$ & $\mathbf{2 0 0 9 / 1 0}$ & $\mathbf{2 0 1 0 / 1 1}$ \\
\hline Made-up textiles & & & & & \\
Equivalent exchange rate & 66.9 & 69.2 & 89.2 & 96.6 & 96.7 \\
Actual exchange rate & 58.4 & 59.4 & 78.5 & 83.8 & 85.5 \\
Difference & 8.5 & 9.8 & 10.7 & 12.8 & 11.2 \\
Percentage change & 14.6 & 16.5 & 13.6 & 15.3 & 13.1 \\
Other textiles & & & & & \\
Equivalent exchange rate & 63.6 & 64.1 & 83.5 & 87.9 & 93.3 \\
Actual exchange rate & 58.4 & 59.4 & 78.5 & 83.8 & 85.5 \\
Difference & 5.2 & 4.8 & 5.0 & 4.1 & 7.8 \\
Percentage change & 8.9 & 8.1 & 6.4 & 4.9 & 9.1 \\
Spinning, weaving and finishing & & & & & \\
Equivalent exchange rate & 59.1 & 64.0 & 80.5 & 89.9 & 92.0 \\
Actual exchange rate & 58.4 & 59.4 & 78.5 & 83.8 & 85.5 \\
Difference & 0.6 & 4.7 & 2.0 & 6.1 & 6.5 \\
Percentage change & 1.0 & 7.9 & 2.5 & 7.3 & 7.6 \\
\hline
\end{tabular}

Note: 50 percent of the income tax on any income from exports will be exempted.

Source: Author's calculations. 
Table A10: Estimated equivalent exchange rate for duty drawbacks

\begin{tabular}{lrrrrr} 
& & & & & $(\mathrm{Rs} / \$)$ \\
\hline Category & $\mathbf{2 0 0 0 / 0 1}$ & $\mathbf{2 0 0 4 / 0 5}$ & $\mathbf{2 0 0 8 / 0 9}$ & $\mathbf{2 0 0 9 / 1 0}$ & $\mathbf{2 0 1 0 / 1 1}$ \\
\hline Made-up textiles & & & & & \\
Equivalent exchange rate & 60.29 & 61.40 & 81.12 & 86.70 & 88.46 \\
Actual exchange rate & 58.43 & 59.35 & 78.49 & 83.80 & 85.50 \\
Difference & 1.85 & 2.05 & 2.63 & 2.90 & 2.96 \\
Percentage change & 3.20 & 3.50 & 3.40 & 3.50 & 3.50 \\
Other textiles & & & & & \\
Equivalent exchange rate & 59.35 & 60.13 & 79.38 & 84.76 & 86.59 \\
Actual exchange rate & 58.43 & 59.35 & 78.49 & 83.80 & 85.50 \\
Difference & 0.91 & 0.78 & 0.88 & 0.96 & 1.09 \\
Percentage change & 1.60 & 1.30 & 1.10 & 1.10 & 1.30 \\
Spinning, weaving and finishing & & & & & \\
Equivalent exchange rate & 58.84 & 59.79 & 79.05 & 84.36 & 86.09 \\
Actual exchange rate & 58.43 & 59.36 & 78.49 & 83.80 & 85.50 \\
Difference & 0.41 & 0.44 & 0.55 & 0.56 & 0.59 \\
Percentage change & 0.70 & 0.74 & 0.70 & 0.67 & 0.69 \\
\hline
\end{tabular}

Note: Duty drawback $=5$ percent.

Source: Author's calculations.

Table A11: Estimated equivalent exchange rate for tax holiday

\begin{tabular}{lrrrrr} 
& & & & & $(\mathrm{Rs} / \mathbf{\text { }})$ \\
\hline Category & $\mathbf{2 0 0 0 / 0 1}$ & $\mathbf{2 0 0 4 / 0 5}$ & $\mathbf{2 0 0 8 / 0 9}$ & $\mathbf{2 0 0 9 / 1 0}$ & $\mathbf{2 0 1 0 / 1 1}$ \\
\hline Made-up textiles & & & & & \\
Equivalent exchange rate & 59.25 & 60.16 & 79.64 & 85.50 & 87.13 \\
Actual exchange rate & 58.43 & 59.35 & 78.49 & 83.80 & 85.50 \\
Difference & 0.81 & 0.81 & 1.14 & 1.69 & 1.63 \\
Percentage change & 1.40 & 1.40 & 1.50 & 2.00 & 1.90 \\
Other textiles & & & & & \\
Equivalent exchange rate & 70.31 & 63.71 & 81.92 & 91.53 & 96.74 \\
Actual exchange rate & 58.44 & 59.36 & 78.50 & 83.80 & 85.50 \\
Difference & 11.87 & 4.35 & 3.42 & 7.72 & 11.24 \\
Percentage change & 20.30 & 7.30 & 4.40 & 9.20 & 13.10 \\
Spinning, weaving and finishing & & & & & \\
Equivalent exchange rate & 59.51 & 60.61 & 79.70 & 85.35 & 87.14 \\
Actual exchange rate & 58.43 & 59.35 & 78.49 & 83.80 & 85.50 \\
Difference & 1.07 & 1.26 & 1.20 & 1.55 & 1.64 \\
Percentage change & 1.8 & 2.10 & 1.50 & 1.80 & 1.90 \\
\hline
\end{tabular}

Source: Author's calculations. 


\section{India's export incentives applied to structure of Pakistani textiles}

Table A12: Estimated equivalent exchange rate for concessional export finance

(Rs/\$)

\begin{tabular}{lrrrrr}
\hline Category & $\mathbf{2 0 0 0 / 0 1}$ & $\mathbf{2 0 0 4 / 0 5}$ & $\mathbf{2 0 0 8 / 0 9}$ & $\mathbf{2 0 0 9 / 1 0}$ & $\mathbf{2 0 1 0 / 1 1}$ \\
\hline Made-up textiles & & & & & \\
Equivalent exchange rate & 62.91 & 63.96 & 84.51 & 90.66 & 93.27 \\
Actual exchange rate & 58.44 & 59.36 & 78.50 & 83.80 & 85.50 \\
Difference & 4.47 & 4.60 & 6.01 & 6.86 & 7.76 \\
Percentage change & 7.60 & 7.70 & 7.70 & 8.20 & 9.10 \\
Other textiles & & & & & \\
Equivalent exchange rate & 75.07 & 67.94 & 91.11 & 95.03 & 99.33 \\
Actual exchange rate & 58.44 & 59.36 & 78.50 & 83.80 & 85.50 \\
Difference & 16.63 & 8.58 & 12.61 & 11.23 & 13.83 \\
Percentage change & 28.50 & 14.50 & 16.10 & 13.40 & 16.20 \\
Spinning, weaving and finishing & & & & & \\
Equivalent exchange rate & 61.65 & 62.88 & 84.53 & 89.29 & 90.97 \\
Actual exchange rate & 58.44 & 59.36 & 78.50 & 83.80 & 85.50 \\
Difference & 3.21 & 3.53 & 6.03 & 5.49 & 5.47 \\
Percentage change & 5.50 & 5.90 & 7.70 & 6.60 & 6.40 \\
\hline
\end{tabular}

Source: Author's calculations.

Table A13: Estimated equivalent exchange rate for duty drawbacks

\begin{tabular}{lrrrrr} 
& & & & & (Rs/\$) \\
\hline Category & $\mathbf{2 0 0 0 / 0 1}$ & $\mathbf{2 0 0 4 / 0 5}$ & $\mathbf{2 0 0 8 / 0 9}$ & $\mathbf{2 0 0 9 / 1 0}$ & $\mathbf{2 0 1 0 / 1 1}$ \\
\hline Made-up textiles & & & & & \\
Equivalent exchange rate & 58.74 & 59.69 & 78.91 & 84.29 & 86.07 \\
Actual exchange rate & 58.44 & 59.36 & 78.50 & 83.80 & 85.50 \\
Difference & 0.31 & 0.33 & 0.42 & 0.49 & 0.57 \\
Percentage change & 0.50 & 0.60 & 0.50 & 0.60 & 0.70 \\
Other textiles & & & & & \\
Equivalent exchange rate & 59.79 & 60.10 & 79.14 & 84.51 & 86.55 \\
Actual exchange rate & 58.44 & 59.36 & 78.50 & 83.80 & 85.50 \\
Difference & 1.35 & 0.74 & 0.64 & 0.71 & 1.04 \\
Percentage change & 2.30 & 1.20 & 0.80 & 0.80 & 1.20 \\
Spinning, weaving and finishing & & & & & \\
Equivalent exchange rate & 58.63 & 59.59 & 78.78 & 84.06 & 85.76 \\
Actual exchange rate & 58.44 & 59.36 & 78.50 & 83.80 & 85.50 \\
Difference & 0.19 & 0.23 & 0.28 & 0.26 & 0.26 \\
Percentage change & 0.33 & 0.39 & 0.36 & 0.31 & 0.30 \\
\hline
\end{tabular}

Source: Author's calculations. 
Table A14: Estimated equivalent exchange rate for zero-rated exports

\begin{tabular}{lrrrrr} 
& & & & & (Rs/\$) \\
\hline Category & $\mathbf{2 0 0 0 / 0 1}$ & $\mathbf{2 0 0 4 / 0 5}$ & $\mathbf{2 0 0 8 / 0 9}$ & $\mathbf{2 0 0 9 / 1 0}$ & $\mathbf{2 0 1 0 / 1 1}$ \\
\hline Made-up textiles & & & & & \\
Equivalent exchange rate & 68.82 & 75.46 & 96.80 & 104.84 & 104.04 \\
Actual exchange rate & 58.44 & 59.36 & 78.50 & 83.80 & 85.50 \\
Difference & 10.38 & 16.10 & 18.30 & 21.04 & 18.54 \\
Percentage change & 17.76 & 27.12 & 23.31 & 25.11 & 21.68 \\
Other textiles & & & & & \\
Equivalent exchange rate & 64.93 & 72.79 & 86.77 & 96.45 & 102.24 \\
Actual exchange rate & 58.44 & 59.36 & 78.50 & 83.80 & 85.50 \\
Difference & 6.49 & 13.43 & 8.27 & 12.65 & 16.74 \\
Percentage change & 11.11 & 22.62 & 10.54 & 15.10 & 19.58 \\
Spinning, weaving and finishing & & & & & \\
Equivalent exchange rate & 68.58 & 73.85 & 89.07 & 99.50 & 102.83 \\
Actual exchange rate & 58.44 & 59.36 & 78.50 & 83.80 & 85.50 \\
Difference & 10.15 & 14.49 & 10.57 & 15.70 & 17.33 \\
Percentage change & 17.37 & 24.41 & 13.46 & 18.74 & 20.27 \\
\hline
\end{tabular}

Source: Author's calculations.

Table A15: Estimated equivalent exchange rate for tax holiday

\begin{tabular}{lrrrrr} 
& & & & & (Rs/\$) \\
\hline Category & $\mathbf{2 0 0 0 / 0 1}$ & $\mathbf{2 0 0 4 / 0 5}$ & $\mathbf{2 0 0 8 / 0 9}$ & $\mathbf{2 0 0 9 / 1 0}$ & $\mathbf{2 0 1 0 / 1 1}$ \\
\hline Made-up textiles & & & & & \\
Equivalent exchange rate & 59.25 & 60.17 & 79.64 & 85.50 & 87.13 \\
Actual exchange rate & 58.44 & 59.36 & 78.50 & 83.80 & 85.50 \\
Difference & 0.81 & 0.81 & 1.14 & 1.70 & 1.63 \\
Percentage change & 1.39 & 1.36 & 1.45 & 2.03 & 1.91 \\
Other textiles & & & & & \\
Equivalent exchange rate & 70.31 & 63.71 & 81.92 & 91.53 & 96.74 \\
Actual exchange rate & 58.44 & 59.36 & 78.50 & 83.80 & 85.50 \\
Difference & 11.87 & 4.35 & 3.42 & 7.72 & 11.24 \\
Percentage change & 20.31 & 7.33 & 4.36 & 9.21 & 13.15 \\
Spinning, weaving and finishing & & & & & \\
Equivalent exchange rate & 59.52 & 60.62 & 79.70 & 85.35 & 87.14 \\
Actual exchange rate & 58.44 & 59.36 & 78.50 & 83.80 & 85.50 \\
Difference & 1.08 & 1.26 & 1.21 & 1.55 & 1.64 \\
Percentage change & 1.85 & 2.12 & 1.54 & 1.85 & 1.92 \\
\hline
\end{tabular}

Source: Author's calculations. 
